\title{
Temperature and phosphorus regulating carbon flux through bacteria in a coastal marine system
}

\author{
Emma S. Kritzberg ${ }^{1,2, *}$, Jesus M. Arrieta ${ }^{1}$, Carlos M. Duarte ${ }^{1}$ \\ ${ }^{1}$ IMEDEA, CSIC-Universitat Illes Balears, Miquel Marques 21, Esporles 07190, Spain \\ ${ }^{2}$ Lund University, Department of Ecology/Limnology, Ecology Building, 22362 Lund, Sweden
}

\begin{abstract}
The aim of this study was to explore the variation and regulation of bacterial carbon processing at a coastal oligotrophic site of the Island of Majorca in the Mediterranean Sea. In situ bacterial production (BP), respiration (BR), growth efficiency, and carbon demand in relation to environmental parameters were studied over an annual cycle. In addition, the response of bacterial carbon processing to an experimental resource (phosphate) and temperature manipulations was tested. While concentrations of dissolved organic carbon (DOC) and phosphorus were fairly stable over the year, BP and BR varied 65-fold and 79-fold, respectively. Addition of phosphate stimulated both BP and BR during most of the year, suggesting that phosphorus limitation keeps a tight rein on bacterial DOC utilization. Both BP and BR responded positively to a $2^{\circ} \mathrm{C}$ experimental increase, but at higher temperature increases BP and BR leveled off or decreased. In situ BP and BR were positively related to temperature, suggesting that elevated water temperature would yield increased BP and BR. BR responded more strongly to temperature than $\mathrm{BP}$, suggesting that increased temperature may result in a decrease in bacterial growth efficiency.
\end{abstract}

KEY WORDS: Bacterial carbon processing - Bacterial growth efficiency · Temperature regulation . Resource regulation $\cdot$ Phosphorus limitation

\section{INTRODUCTION}

Marine dissolved organic carbon (DOC) is among the largest organic carbon $(\mathrm{C})$ reservoirs on Earth, equal to the size of the atmospheric $\mathrm{CO}_{2}$ pool, and a key component in the global C cycle. The stocks and transformations of DOC are largely regulated by heterotrophic bacterioplankton, which use DOC to support their metabolism. To the extent that it is bioavailable, bacteria convert organic $\mathrm{C}$ into bacterial biomass (bacterial production, $\mathrm{BP}$ ) or respire it to $\mathrm{CO}_{2}$ (bacterial respiration, $\mathrm{BR}$ ). $\mathrm{BP}$ and $\mathrm{BR}$ make up the bacterial $\mathrm{C}$ demand (BCD) and represent the largest $C$ flow in most aquatic systems (Cole 1999). Bacterial growth efficiency $(B G E=B P / B P+B R)$ describes the fraction of $B C D$ used to support growth.

Because of their large bearing on $\mathrm{C}$ flow in marine pelagic ecosystems, constraining $\mathrm{BCD}$ and $\mathrm{BGE}$ values over temporal and spatial scales is imperative to better understand and model aquatic $\mathrm{C}$ cycling. Likewise, re- solving the factors governing variability in $\mathrm{BCD}$ and BGE is essential to predict how aquatic ecosystems and C biogeochemistry will respond to environmental change. Substrate/resources and temperature are the main factors influencing bacterial $\mathrm{C}$ processing, although e.g. viral phages, predation, and bacterial community composition and predation may also affect bacterial function (del Giorgio et al. 1996, del Giorgio \& Cole 1998, Cottrell \& Kirchman 2000, Fischer \& Velmirov 2002, Riemann \& Middelboe 2002, Apple et al. 2006).

The amounts and quality of the organic matter substrate as well as the availability of inorganic nutrients have been shown to affect bacterial $\mathrm{C}$ processing. At very low organic substrate concentrations, bacterial C processing will be impaired and a larger fraction of the available $\mathrm{C}$ may be used for catabolic rather than anabolic processes (Eiler et al. 2003). However, most studies suggest that the quality rather than quantity of organic 
substrates regulates bacterial C processing (Vallino et al. 1996), as total DOC pools are orders of magnitude greater than BCDs in most aquatic ecosystems. For example, some substrates require enzymatic hydrolysis before uptake (Middelboe \& Sondergaard 1993), and different organic molecules exhibit different energy to C ratios, which will pose limits to bacterial utilization and growth efficiency (Vallino et al. 1996). Moreover, bacteria may regulate the catabolism of organic substrates to attain the correct intracellular stoichiometry with respect to nutrients, such that substrates with high nutrient to $\mathrm{C}$ ratio should be more efficiently utilized as they better satisfy the high nutrient demand of bacteria (bacterial C:N:P 50:10:1, Fagerbakke et al. 1996). As predicted by ecological stoichiometric theory, BGE has been shown to decline with increasing C:N and C:P ratios of natural organic substrates (Kroer 1993, Lennon \& Pfaff 2005). When the nutrient content of the organic substrates is too low, the presence of inorganic nutrients may result in higher substrate utilization and growth efficiency (Kroer 1993, Kragh et al. 2008). On the basis of a large cross system analysis, del Giorgio \& Cole (1998) concluded that BGE is controlled mainly by $\mathrm{BP}$ and is related to the availability of nutrients and organic $C$, suggesting that bacterial C processing is predominantly controlled by resources.

Temperature is an ever-present factor affecting all chemical and biochemical processes and influencing bacterial C processing through e.g. regulation of cellular metabolism and substrate affinity. Rivkin \& Legendre (2001) derived a negative relationship between temperature and BGE. Inherent in this model is that BR responds more strongly to temperature than $\mathrm{BP}$, i.e. for BGE to decrease with increasing temperature, BR must increase faster than BP. The correlation reported by Rivkin \& Legendre (2001) is based on a comparative analysis across broad spatial scales and does not imply a direct functional relationship between temperature and BGE. For instance, resource availability often covaries with temperature in the surface ocean, and it has been argued that in regions with higher temperature, maintenance costs are high while substrate concentrations are low, leading to low BGE. In low temperature regions, the low metabolic rate may be compensated for by higher substrate concentrations (Pomeroy \& Wiebe 2001). The co-variation of temperature with other factors over geographical regions does not allow for a functional analysis of the mechanisms that control BGE to be derived solely from comparative analyses; therefore, experimental approaches are needed to mechanistically resolve these effects.

The aim of this study was to establish $C$ flux through bacterioplankton in a coastal oligotrophic system and to experimentally test how the different components of this flux (BP, BR, BGE, and BCD) are regulated. Special emphasis was put on the role of resources and temperature. We used a dual approach, combining in situ measurements of bacterial $\mathrm{C}$ processing and environmental variability along an annual cycle with repeated experiments where resources and temperature were manipulated. The study was performed in a highly oligotrophic area of the coast of Majorca Island, western Mediterranean Sea, a region reported to be strongly phosphorus (P) deficient (Thingstad et al. 1998, Moutin \& Raimbault 2002) and where BP has been shown to be P limited (Thingstad et al. 1998, Van Wambeke et al. 2002, Pinhassi et al. 2006). Therefore, experimental assessment of the regulation of bacterial $\mathrm{C}$ processing by resources focused on testing the effects of phosphate additions. We hypothesized that $\mathrm{P}$ and temperature are both limiting factors for BP and $\mathrm{BR}$ in this system. We further tested the hypothesis that $\mathrm{BP}$ is more strongly regulated by $\mathrm{P}$ than is $\mathrm{BR}$, while $\mathrm{BR}$ is more strongly regulated by temperature than is BP.

\section{MATERIALS AND METHODS}

Water was collected from the highly oligotrophic area (mean \pm SE for 30 measurements from 2005 to 2008: $0.27 \pm 0.03 \mu \mathrm{g}$ chlorophyll $a\left[\mathrm{chl} \mathrm{a} \mathrm{l}^{-1}, 0.047 \pm\right.$ $0.001 \mu \mathrm{mol}$ soluble reactive $\mathrm{P}$ [SRP] $\mathrm{l}^{-1}, 0.64 \pm$ $0.23 \mu \mathrm{mol} \mathrm{NO}{ }^{-}+\mathrm{NO}_{2}{ }^{-} \mathrm{l}^{-1}$, and $0.42 \pm 0.03 \mu \mathrm{mol}$ silicate $\mathrm{I}^{-1} ; \mathrm{C}$. Duarte unpubl.) adjacent to the coastal station of Cap de Ses Salines Lighthouse $\left(39^{\circ} 20^{\prime} \mathrm{N}, 3^{\circ} 03^{\prime} \mathrm{E}\right)$ located at the southern tip of the island of Majorca, Spain. The depth of the sampling site varies from 1.5 to $2.5 \mathrm{~m}$ over the year due to shifting sand. Samples were taken at $0.5 \mathrm{~m}$ depth using an acid-rinsed $10 \mathrm{l}$ carboy. A total of 19 sampling events took place between June 2006 and August 2007, including incubations for BP and respiration BR. Concurrently with bacterial incubations, water temperature was recorded and samples taken for nutrients, DOC, and chl a. On 15 of the sampling occasions, samples receiving experimental addi-

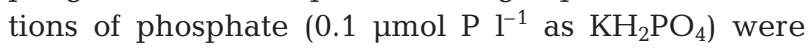
incubated in parallel with unamended samples, to assess the potential effect of increased $\mathrm{P}$ concentrations on bacterial C processing. On 2 occasions, at the time of minimum and maximum water temperature (27 February and 28 August), bacterial incubations were made at 4 different temperatures (in situ, $+2,+4$, and $+6^{\circ} \mathrm{C}$ ), in order to assess the potential effect of elevated water temperatures on bacterial $\mathrm{C}$ processing.

$\mathrm{BP}$ and $\mathrm{BR}$ were measured on water that had been filtered through $0.8 \mu \mathrm{m}$ polycarbonate filters (Poretics) to remove phytoplankton and bacterial grazers; additionally, in situ BP was measured on unfiltered water. The filtration step reduced BP by $36 \pm 25 \%$ (mean \pm $\mathrm{SD}$ ). The filtered water was siphoned into $70 \mathrm{ml}$ BOD 
bottles. For each treatment, 3 bottles were used to measure BP at time 0 and after $24 \mathrm{~h}$. Another 12 identical bottles for each treatment were used to estimate BR. All bottles were kept in darkness at in situ temperature, or at 2,4 , or $6^{\circ} \mathrm{C}$ above in situ temperature. During winter, the water temperature was stable over the $24 \mathrm{~h}$ cycle and varied by less than $0.3^{\circ} \mathrm{C}$. Therefore, the incubations in winter were made in thermostats at fixed temperatures: in situ or 2,4 , and $6^{\circ} \mathrm{C}$ above in situ temperature. During summer, the temperature varied by up to $2.5^{\circ} \mathrm{C}$ over $24 \mathrm{~h}$ and therefore incubations were made in situ. For the temperature manipulation experiment carried out in summer, the incubations were in serially coupled reservoirs fed with surface seawater. The recirculation rate was set so that water warmed up in its path through the system by about $2^{\circ} \mathrm{C}$ from 1 reservoir to the next. This warming resulted in temperatures in the second, third, and fourth reservoirs being higher by 2,4 , and $6^{\circ} \mathrm{C}$ than the temperature of the first reservoir receiving water at the in situ temperature and following closely the $2.5^{\circ} \mathrm{C}$ variation observed over the $24 \mathrm{~h}$ cycle in surface waters.

BP was estimated by measuring incorporation of ${ }^{3} \mathrm{H}$ leucine following the method developed by Smith \& Azam (1992). Water samples $(1.5 \mathrm{ml}, 3$ replicates and 1 killed control) were incubated with $90 \mathrm{nM}$ final concentration of ${ }^{3} \mathrm{H}$-leucine $\left(26.3 \mathrm{Ci} \mathrm{mmol}^{-1}\right)$ for $60 \mathrm{~min}$. The incubation was terminated with TCA (5\% final concentration). The samples were then centrifuged at $17000 \times g(10 \mathrm{~min})$ and the supernatant discarded. Subsequently, the pellet was rinsed twice with $5 \%$ TCA. After the supernatant was discarded, $0.5 \mathrm{ml}$ of scintillation cocktail (Optifluor, Perkin Elmer) was added and ${ }^{3} \mathrm{H}$-activity measured with a Beckman scintillation counter. BP was calculated according to Smith \& Azam (1992) assuming a leucine to C conversion factor of $1.5 \mathrm{~kg} \mathrm{C} \mathrm{mol}^{-1}$ leucine.

BR was estimated from the consumption of dissolved oxygen in BOD bottles assuming a respiratory quotient of 1. Six samples were immediately fixed with Winkler reagents and used to measure initial oxygen concentration. The remaining 6 bottles were fixed after $24 \mathrm{~h}$. Oxygen concentrations were analyzed by high-precision Winkler titration using a potentiometric electrode and automated endpoint detection (Mettler Toledo, DL28 titrator).

BGE was estimated from measurements on the $0.8 \mu \mathrm{m}$ filtered water and calculated as accumulated BP over accumulated BR and accumulated BP. Since bacteria typically grow during these experiments, and oxygen consumption is an integrated measurement of BR accumulated over $24 \mathrm{~h}$, using the accumulated BP as an integrated measure of BP over $24 \mathrm{~h}$ allows for a more accurate estimate of BGE. To calculate the accumulated $\mathrm{BP}$ over $24 \mathrm{~h}$, values of BP at time 0 and $24 \mathrm{~h}$ were inte- grated assuming that bacteria were growing at an exponential rate (following Roland \& Cole 1999). Since $0.8 \mu \mathrm{m}$ filtration reduced bacterial activity, oxygen consumption from the incubations underestimates the in situ BR. Instead, in situ BR was estimated from BGE and in situ BP, assuming that BGE derived from the filtered samples is an accurate estimate of in situ BGE.

$$
\mathrm{BR}_{\text {in situ }}=\frac{\mathrm{BP}_{\text {in situ }}}{\mathrm{BGE}}-\mathrm{BP}_{\text {in situ }}
$$

Whereas bacterial activity was reduced somewhat by the retention of bacterial cells on the $0.8 \mu \mathrm{m}$ filter, BGE should not be affected since BGE is independent of population size.

DOC samples $(10 \mathrm{ml})$ were filtered through pre-combusted $0.7 \mu \mathrm{m}$ Whatman $\mathrm{GF} / \mathrm{F}$ filters $\left(450^{\circ} \mathrm{C}\right.$ for $\left.4.5 \mathrm{~h}\right)$, transferred to pre-combusted glass ampoules, and kept acidified (pH: 1 to 2) until analysis on a Shimadzu TOC-5000A. Standards of 44 to 45 and $2 \mu \mathrm{mol} \mathrm{C} \mathrm{l}^{-1}$ (provided by D.A. Hansell and W. Chen, University of Miami), were used to assess the accuracy of the measurements. Duplicate samples of $150 \mathrm{ml}$ were filtered through $0.7 \mu \mathrm{m}$ Whatman GF/F filters, stored frozen, and subsequently extracted with acetone before fluorometric determination of $\mathrm{chl}$ a concentration (Parsons et al. 1984). Unfiltered samples for the determination of the concentrations of SRP (including phosphate as well as acid labile dissolved organic $\mathrm{P}$, detection limit $0.01 \mathrm{~mol} \mathrm{l}^{-1}$ ), total nitrogen (TN), and total P (TP) were kept frozen until analyzed following standard spectrophotometric methods (Hansen \& Koroleff 1999).

Correlations were tested with Pearson correlations and coefficients (r) are given. When necessary, data was ln- or arcsine-transformed to meet assumptions of normal distribution. Relationships between BGE with and without $\mathrm{P}$ amendments were tested with linear regressions (Model I), and coefficients of determination $\left(\mathrm{R}^{2}\right)$ are given. The residuals were tested for normal distribution and independence of the independent variable. The effect of treatments was tested by $t$-test and paired-samples $t$-test between the control and experimental treatments. All statistical analyses were performed using SPSS 16 for Macintosh. Values of $Q_{10}$ (e.g. $\left[\mathrm{BP}_{\mathrm{T} 2} / \mathrm{BP}_{\mathrm{T} 1}\right]^{10 /(\mathrm{T} 2-\mathrm{T} 1)}$ where $\mathrm{T} 1$ and $\mathrm{T} 2$ are 2 different in situ temperatures) were computed from the equation of fitted lines between temperature and BP and $\mathrm{BR}$, respectively.

\section{RESULTS}

The water temperature at the sampling site varied between $14.4^{\circ} \mathrm{C}$ in January and $28.2^{\circ} \mathrm{C}$ in July of 2007 (Table 1). There were no clear seasonal trends in TP (range 0.11 to $0.39 \mu \mathrm{mol} \mathrm{P} \mathrm{l}^{-1}$ ) or SRP (range 0 to 
Table 1. Environmental variables and response in bacterial $\mathrm{C}$ processing to $\mathrm{P}$ additions. nd: not determined. $+/--:$ average increase/decrease by 10 to $20 \%$ compared to unamended controls $;++$ and +++: average change of 20 to $50 \%$ and $>50 \%$, respectively; -: average change $<10 \%$; DOC: dissolved organic carbon; TN: total nitrogen; TP: total phosphorus; SRP: soluble reactive phosphorus; BP: bacterial production; BR: bacterial respiration; BCD: bacterial carbon demand

\begin{tabular}{|c|c|c|c|c|c|c|c|c|c|}
\hline \multirow[t]{2}{*}{ Date } & \multirow{2}{*}{$\begin{array}{l}\text { Temp } \\
\left({ }^{\circ} \mathrm{C}\right)\end{array}$} & \multirow{2}{*}{$\begin{array}{c}\text { Chl a } \\
\left(\mu g \mathrm{l}^{-1}\right)\end{array}$} & \multirow{2}{*}{$\begin{array}{l}\text { DOC } \\
(\mu M)\end{array}$} & \multirow{2}{*}{$\begin{array}{l}\mathrm{TN} \\
(\mu \mathrm{M})\end{array}$} & \multirow{2}{*}{$\begin{array}{c}\text { TP } \\
(\mu \mathrm{M})\end{array}$} & \multirow{2}{*}{$\begin{array}{l}\text { SRP } \\
(\mu M)\end{array}$} & \multicolumn{3}{|c|}{ Response to $\mathrm{P}$ addition } \\
\hline & & & & & & & $\mathrm{BP}$ & $\mathrm{BR}$ & $\mathrm{BCD}$ \\
\hline 7 Jun 06 & 20 & 0.08 & 63 & 4.6 & 0.16 & $<0.01$ & nd & nd & nd \\
\hline 21 Jun 06 & 22.6 & 0.11 & 65 & 4.8 & 0.17 & $<0.01$ & +++ & +++ & +++ \\
\hline $12 \mathrm{Jul} 06$ & 26.6 & 0.19 & nd & 5.0 & 0.16 & $<0.01$ & - & + & + \\
\hline 18 Jul 06 & 28 & 0.19 & nd & 5.3 & 0.23 & 0.04 & nd & nd & nd \\
\hline 4 Aug 06 & 28 & 0.35 & 67 & 5.2 & 0.20 & $<0.01$ & ++ & ++ & ++ \\
\hline 30 Aug 06 & 26.2 & 0.11 & 69 & 9.2 & 0.36 & 0.18 & ++ & + & ++ \\
\hline 28 Sep 06 & 25 & 0.16 & 75 & 3.4 & 0.16 & 0.09 & - & + & - \\
\hline 11 Nov 06 & 21 & 0.16 & 91 & 3.8 & 0.13 & 0.02 & ++ & +++ & +++ \\
\hline 22 Nov 06 & 19.5 & nd & 129 & 5.5 & 0.22 & 0.06 & nd & nd & nd \\
\hline 6 Dec 06 & 18.3 & 2.1 & 106 & 8.7 & 0.39 & 0.27 & +++ & ++ & ++ \\
\hline 19 Dec 06 & 15.5 & 0.33 & 177 & 3.0 & 0.11 & 0.05 & nd & nd & nd \\
\hline 11 Jan 07 & 15.5 & 0.32 & 40 & 3.9 & 0.11 & 0.07 & +++ & +++ & +++ \\
\hline 31 Jan 07 & 14.4 & 0.34 & 79 & 11.9 & 0.12 & 0.06 & + & + & + \\
\hline 15 Feb 07 & 15.5 & 0.28 & 100 & 11.9 & 0.24 & 0.04 & ++ & ++ & ++ \\
\hline 27 Feb 07 & 15.3 & 0.23 & 188 & 5.7 & 0.20 & 0.05 & - & - & - \\
\hline 14 Mar 07 & 15.8 & 0.3 & 74 & 3.9 & 0.16 & 0.03 & - & + & - \\
\hline 24 May 07 & 20 & 0.13 & nd & 5.6 & 0.13 & 0.03 & +++ & - & + \\
\hline 21 Jun 07 & 24 & 0.19 & 95 & 4.9 & 0.12 & 0.01 & ++ & -- & -- \\
\hline 28 Aug 07 & 28.2 & nd & 103 & 1.1 & 0.26 & 0.12 & ++ & - & + \\
\hline
\end{tabular}

$\left.0.27 \mu \mathrm{mol} \mathrm{P} \mathrm{l}^{-1}\right)$. SRP concentration was low $(<0.1 \mu \mathrm{mol}$ $\mathrm{P}^{-1}$ ) throughout the year except for 3 dates, and the $\mathrm{P}$ pool was dominated by organic P $(71 \pm 21 \%)$ that may not be available to bacteria. The molar TN:TP ratio was quite high, averaging $32( \pm 19)$ and above 21 on all but the last date of sampling, providing indications of $\mathrm{P}$ deficiency in the system. DOC varied from 63 to $188 \mu \mathrm{M}$ and was not related to any other environmental variables. Chl a was generally low and varied between 0.08 and $0.35 \mu \mathrm{g} \mathrm{l}^{-1}$, except for a single higher measurement in December $\left(2.1 \mu \mathrm{g}^{-1}\right)$. This was shortly after a storm and coincided with the highest measurements of TP and SRP (Table 1). Neither chl a nor any of the bacterial parameters showed any significant correlation with any of the nutrient concentrations.

$B P$ varied 65-fold between 0.009 and $0.6 \mu \mathrm{C} \mathrm{Cl}^{-1} \mathrm{~h}^{-1}$, and BR varied 79-fold between 0.038 and $3.0 \mu \mathrm{g} \mathrm{C}^{-1}$ $\mathrm{h}^{-1}$. BP, BR, and BCD were all positively related to temperature (Table 2, Fig. 1). $Q_{10}$ for BP over the in situ temperature range was $4.3(\mathrm{LnBp}=\operatorname{LnTemp} \times 2.87-$ $\left.3.55, \mathrm{R}^{2}=0.41, \mathrm{p}<0.01\right)$, while it was $7.6(\mathrm{LnBR}=$ LnTemp $\left.\times 3.98-6.07, R^{2}=0.52, p<0.001\right)$ for BR. Hence, over the sampling period BR was more strongly affected by temperature than BP. BP and BR were well correlated (Fig. 2, Table 2). BR showed the strongest correlation with BGE, which decreased with increasing $B R$, while there was no significant relationship between BGE and BP (Table 2). BGE varied between 0.12 and 0.51 (average 0.32) and although the highest values were recorded during winter and the lowest in summer, the relationship between BGE and temperature was not significant. However, the BGE in Pamended treatments showed a significant and negative relationship with temperature (Table 2). Also, the relationship between BR and temperature was stronger in $\mathrm{P}$-amended treatments $(\mathrm{r}=0.71, \mathrm{p}<0.01)$ than in unamended samples ( $\mathrm{r}=0.63, \mathrm{p}<0.01)$.

Addition of $\mathrm{P}$ generally stimulated $\mathrm{BP}, \mathrm{BR}$, and $\mathrm{BCD}$ (BP + BR, Table 1, Fig. 3). BP, BR, and BCD were significantly higher in $\mathrm{P}$-amended treatments than in the controls in $73 \%$ of the experiments, and by pair-wise comparison, $\mathrm{BP}, \mathrm{BR}$ and $\mathrm{BCD}$ were all higher in $\mathrm{P}$ amended treatments ( $p<0.01$, Fig. 3$)$. BP, BR, and BCD rates were on average 1.3 times higher (range 0.73 to 2.60) in P-amended treatments compared to controls.

Table 2. Correlation coefficients (r), probability (p), and number of observations for bacterial variables and temperature. $\mathrm{BP}$ : bacterial production; BR: bacterial respiration; BCD: bacterial carbon demand; BGE: bacterial growth efficiency

\begin{tabular}{|lccc|}
\hline Variables & $\mathrm{r}$ & $\mathrm{p}$ & $\mathrm{n}$ \\
\hline $\mathrm{BP}_{\text {in situ }}$ - temp & 0.64 & 0.004 & 19 \\
$\mathrm{BR}_{\text {in situ }}$ - temp & 0.71 & 0.001 & 18 \\
$\mathrm{BCD}$ - temp & 0.71 & 0.001 & 18 \\
$\mathrm{BGE}$ - temp & -0.46 & 0.065 & 18 \\
$\mathrm{BGE}_{\mathrm{P}}$ - temp & -0.69 & 0.004 & 15 \\
$\mathrm{BP}_{\text {in situ }}-\mathrm{BR}_{\text {in situ }}$ & 0.80 & 0.000 & 18 \\
$\mathrm{BP}_{\text {- BGE }}$ & -0.11 & 0.660 & 18 \\
$\mathrm{BR}-\mathrm{BGE}$ & -0.68 & 0.003 & 18 \\
\hline
\end{tabular}




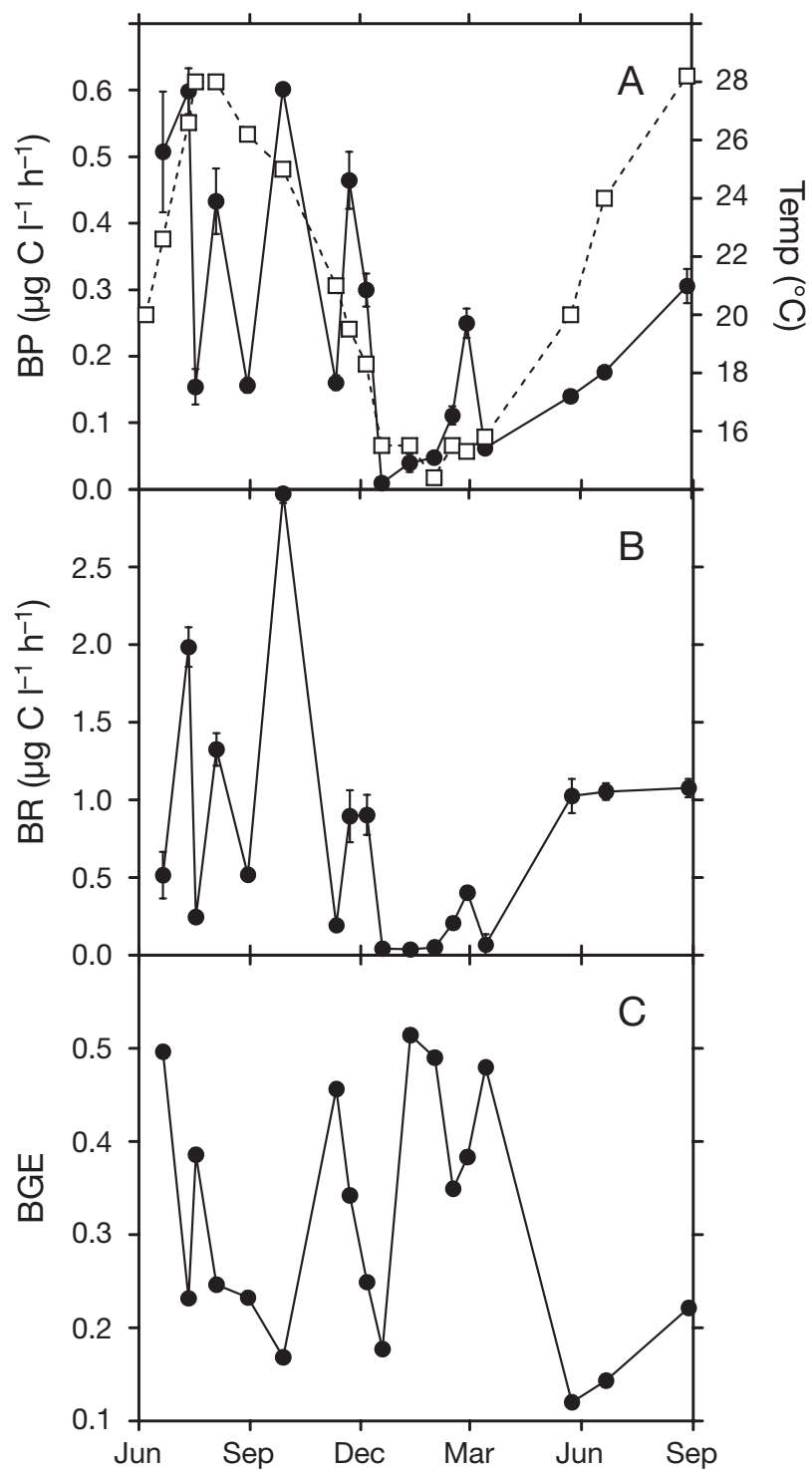

Fig. 1. Time series of (A) bacterial production (BP, solid line) and temperature (dashed line), (B) bacterial respiration (BR), and (C) bacterial growth efficiency (BGE). Error bars denote $\pm 1 \mathrm{SE}$
Moreover, the response of $\mathrm{BP}$ and $\mathrm{BR}$ to $\mathrm{P}$ additions was not completely matched in time and was variable in relative magnitude, so that the response of BGE to $\mathrm{P}$ addition was highly variable, ranging from negative to positive. Hence, there was no difference between BGE with and without $\mathrm{P}$ amendments by pair-wise comparison $(p=0.77)$. However, at relatively high in situ BGE (>0.30), BGE was reduced upon P amendment, whereas at relatively low in situ BGE, $\mathrm{P}$ additions resulted in increasing $B G E$, such that the slope of the relationship between BGE with and without $\mathrm{P}$ amendments was significantly $<1$ and the intercept was significantly $>0$ ( $\mathrm{p}<0.01$, Fig. 3D). The response in $\mathrm{BP}$, $\mathrm{BR}, \mathrm{BCD}$, or BGE was independent of the in situ concentrations of TP or SRP as tested by correlation analysis $(p>0.05)$. It should be noted that the measurements of SRP include acid labile organic $P$ that may not be available to bacteria. While SRP is supposed to provide an indication of the readily available fraction of $\mathrm{P}$ available for biological uptake, it may not accurately represent the concentration of $\mathrm{P}$ actually available to the bacterial communities (Wetzel \& Likens 2000), as this is dependent on a large number of factors, including the nature of the DOC pool accessible to bacteria, and concentrations of other elements as well. During the $24 \mathrm{~h}$ incubations, BP increased strongly. BP after $24 \mathrm{~h}$ was on average 20 times higher than at time 0 , the average in situ BP was $0.25 \mu \mathrm{g} \mathrm{l}^{-1} \mathrm{~h}^{-1}$ and the average BP after $24 \mathrm{~h}$ of incubation was $1.5 \mu \mathrm{g} \mathrm{l}^{-1} \mathrm{~h}^{-1}$.

The temperature manipulations were made once in wintertime at an in situ temperature of $15^{\circ} \mathrm{C}$, and once in summertime when the in situ temperature was $28^{\circ} \mathrm{C}$. There was an overall tendency that increasing the temperature by $2^{\circ} \mathrm{C}$ resulted in increased BP and BR (Fig. 4). Moreover, there was a general tendency that $\mathrm{BP}$ and BR either leveled off or decreased when the temperature was increased by more than $2{ }^{\circ} \mathrm{C}$. BGE did not change in response to temperature in the winter experiment, whereas it decreased at elevated temper-

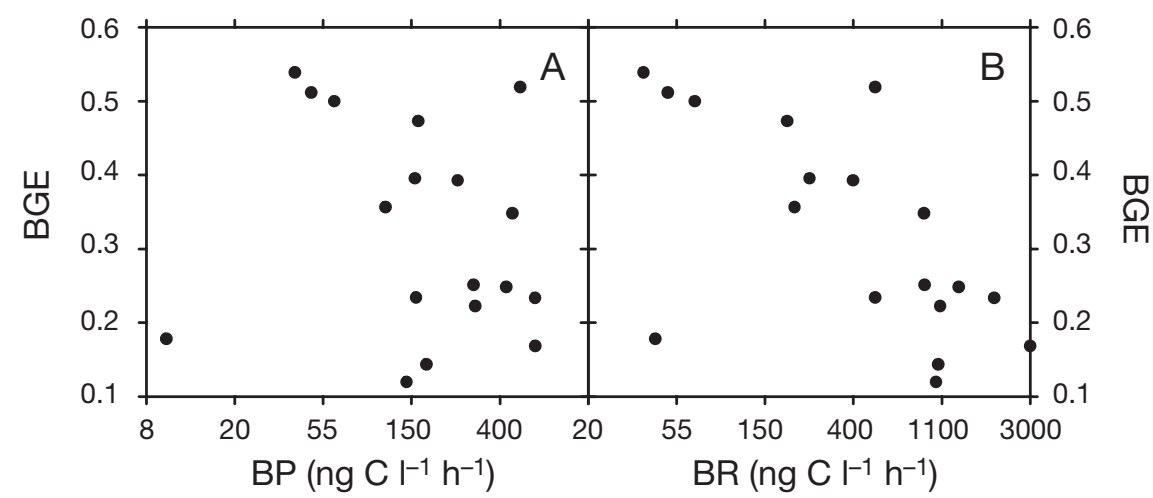

Fig. 2. Relationship between bacterial growth efficiency (BGE) and (A) bacterial production (BP) and (B) bacterial respiration (BR). BGE was inversely related to BR (ArcsinBGE vs. LnBR; $r=-0.68, p<0.01)$. Note that the axes are arcsin $(y)$ and ln scale $(x)$ 


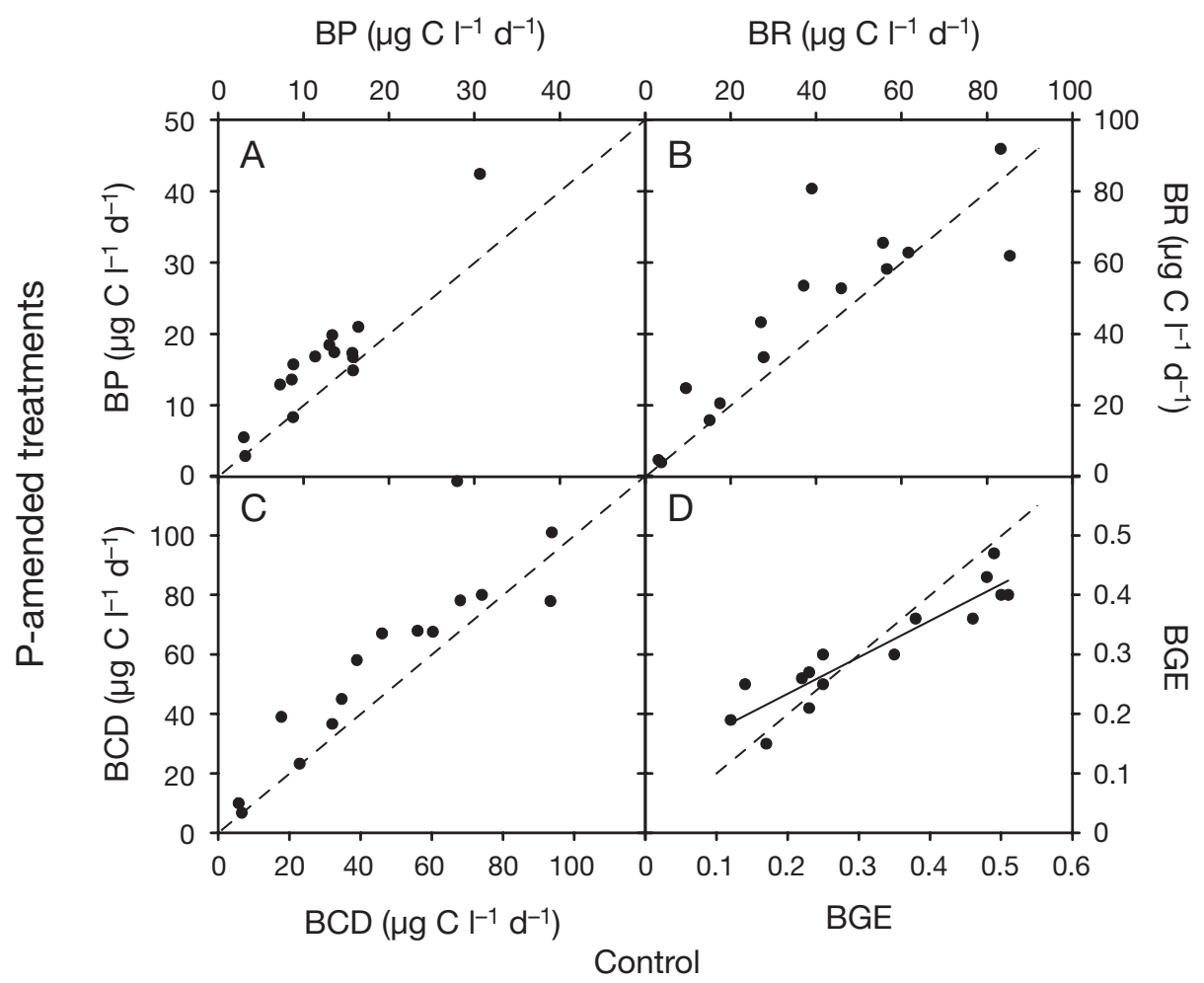

Fig. 3. Comparisons of (A) accumulated bacterial production (BP), (B) respiration (BR), (C) carbon demand (BCD), and (D) growth efficiency (BGE) with ( $y$-axis) and without ( $x$-axis) P additions. Dashed line indicates the 1:1 correspondence. Continuous line in (D) corresponds to the regression fit. Note that the slope of the line is significantly $<1$ and the intercept is significantly $>0$ $\left(\mathrm{BGE}+\mathrm{P}=\mathrm{BGE} \times 0.62+0.11 ; \mathrm{R}^{2}=0.85, \mathrm{p}<0.01\right)$

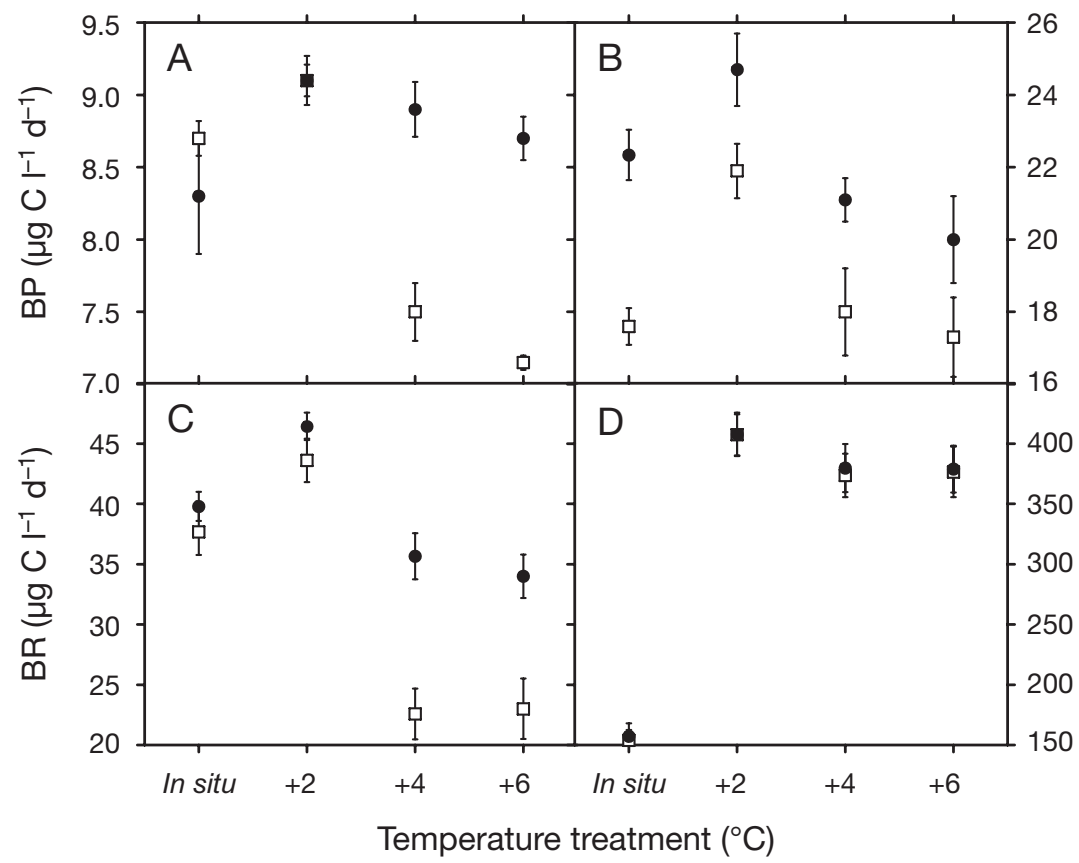

Fig. 4. Bacterial response to temperature manipulations. Squares: unamended treatments; filled circles: P-amended treatments. Error bars denote $\pm 1 \mathrm{SD}$. (A) and (B) show the bacterial production (BP) at different temperature increments in winter and summer, respectively. (C) and (D) show the bacterial respiration (BR) 
Table 3. Values of bacterial growth efficiency in temperature experiments during winter and summer with $(+\mathrm{P})$ and without (C) P amendments

\begin{tabular}{|lccccc|}
\hline \multirow{2}{*}{$\begin{array}{l}\text { Incubation } \\
\text { temperature }\end{array}$} & \multicolumn{3}{c}{ Winter } & & \multicolumn{3}{c|}{ Summer -} \\
& & $+\mathrm{P}$ & & $\mathrm{C}$ & $+\mathrm{P}$ \\
\hline In situ & 0.38 & 0.36 & 0.23 & 0.27 \\
$+2^{\circ} \mathrm{C}$ & 0.36 & 0.34 & 0.13 & 0.14 \\
$+4^{\circ} \mathrm{C}$ & 0.36 & 0.35 & 0.11 & 0.13 \\
$+6^{\circ} \mathrm{C}$ & 0.37 & 0.34 & 0.11 & 0.12 \\
\hline
\end{tabular}

atures in the summer experiment (Table 3). At the time of the winter experiment, neither BP nor BR was stimulated by $\mathrm{P}$ additions, while in the summer experiment, BP, but not BR, was enhanced upon $\mathrm{P}$ addition (Table 1).

\section{DISCUSSION}

The aim of this study was to explore the variation and regulation of bacterial $\mathrm{C}$ processing over an annual cycle at a coastal site on the Island of Majorca, Spain. We studied the in situ BP, BR, BGE, and C consumption in relation to environmental parameters, and tested their response to experimental manipulations of phosphate concentration and temperature. Sampling was made near the shore, where organic matter pools could be affected by seagrass (Posidonia oceanica) DOC release (cf. Barrón \& Duarte 2009). Nevertheless, nutrient concentrations, chl $a, \mathrm{BP}$, and $\mathrm{BR}$ were all within the range of values previously measured in open water sites in the NW Mediterranean (Lemée et al. 2002, Navarro et al. 2004, Alonso-Saez et al. 2008). Moreover, the concentrations of DOC and P were fairly stable (Table 1) and did not vary seasonally as they typically do in open and periodically stratified sites of the Mediterranean (Pinhassi et al. 2006).

$\mathrm{BP}, \mathrm{BR}$, and BGE varied widely over the annual cycle. As TP and SRP concentrations were rather invariable over the year, changes in $\mathrm{P}$ concentrations could not explain the large variability in bacterial $\mathrm{C}$ processing. However, the high $\mathrm{N}: \mathrm{P}$ ratios at the site, as well as the prevalence of bacterial response to $\mathrm{P}$ additions, suggested bacterial C processing to be P limited. Both BP and BR were stimulated by $\mathrm{P}$ additions in 11 out of 15 experiments. $\mathrm{P}$ is a vital nutrient to bacteria, forming compounds with structural and metabolic functions such as protein synthesis, cell production, and energy transport. Thus, it is expected that it limits both growth and respiration in a P-starved system such as the Mediterranean or Sargasso Sea (Obernosterer et al. 2003). The finding that BP and BR were not always stimulated by $\mathrm{P}$ additions implies that other factors are involved, such as organic substrate quality and temperature. In the Bay of Blanes in the western Mediterranean, which is affected by urban and riverine discharges and is not as oligotrophic as our study site (Duarte et al. 2004), BP was strongly stimulated by addition of phosphate during stratified summer conditions, while there was little or no response during nonstratified winter conditions when phosphate and chl a levels were higher (Pinhassi et al. 2006). When BP was not stimulated by $\mathrm{P}$ additions, it was stimulated by glucose additions, indicating that the quality of the ambient DOC at Blanes Bay was limiting BP during this period. These and several other studies (Thingstad et al. 1998, Zohary \& Robarts 1998) suggest that bacterial $\mathrm{P}$ limitation controls the capacity of bacteria to use the DOC pool of these systems during most of the year, with important consequences to the biogeochemical $\mathrm{C}$ processing driven by bacteria.

We tested the hypothesis that BP would be more strongly limited by $\mathrm{P}$ than BR, which implies that BGE would be limited by $\mathrm{P}$. The reasoning behind this is that as long as the C:P ratio of the substrate is higher than that of bacterial biomass, anabolic processes will be more strongly limited by $\mathrm{P}$ than will catabolic processes, which do not represent a net sink for P. Consistent with this theory, Kragh et al. (2008) observed sustained bacterial activity and higher BGE on natural organic substrates amended with phosphate. Similarly, BGE has been demonstrated to have a positive relationship with the availability of P in lakes (Smith \& Prairie 2004). In our study, the effect of phosphate additions on BGE was dependent on the level of BGE. BGE was enhanced after $P$ additions when BGE in the control was low $(<30 \%)$, but no increase in BGE upon $\mathrm{P}$ additions was observed when BGE was already high (Fig. 3D). A low BGE in the control indicates that bacterial $\mathrm{C}$ use was dominated by catabolic processes, and the positive response upon $\mathrm{P}$ additions suggest that BGE was limited by the availability of P. However, BGE cannot increase continuously, as bacteria must respire to be able to grow, and BR is often 2-fold higher than BP even under resource-saturated conditions (del Giorgio and Cole 1998, López-Urrutia \& Morán 2007). Hence, high BGE (>30\%) indicates that anabolic processes were operating near their maximum and that bacteria were utilizing high-quality substrates with low C:P ratio and high energy:C ratio (Vallino et al. 1996). Upon addition of phosphate, previously unavailable low-quality substrates with high C:P ratio and low energy: $C$ ratio became available and therefore $B R$ was stimulated more than BP. Hence, $\mathrm{P}$ additions should result in increased BGE when bacteria are growing on a high energy: C ratio, but P-deficient substrate. However, the response of bacteria growing on a heterogeneous substrate, including both high and low energy: $\mathrm{C}$ 
ratio compounds is less predictable. Other studies point in the same direction, e.g. in 3 lakes where BGE was stimulated by phosphate additions compared to the control, BGE was lower in treatments where both phosphate and glucose (low energy: $\mathrm{C}$ ratio) was added than in treatments with phosphate alone (Smith \& Prairie 2004). Similarly, while BGE has been shown to be inversely related to $\mathrm{C}: \mathrm{N}$ ratios of singular organic substrates (Goldman et al. 1987), the relationship between BGE and available $\mathrm{C}: \mathrm{N}$ was considerably weaker when bacteria had access to multiple C and N sources (Goldman \& Dennett 1991). Returning to the hypotheses, BP, BR, and hence BCD were indeed limited by $\mathrm{P}$ during the major part of the year. However, based on the response to the $\mathrm{P}$ additions, $\mathrm{BP}$ was not more limited by $\mathrm{P}$ than BR, and BGE was not consistently P limited.

It was further hypothesized that bacterial $\mathrm{C}$ processing would be temperature limited. From the time series data, both BP and BR seem to be partly regulated by temperature, as BP and BR tended to be higher in the summer. As much as 41 and $52 \%$ of the temporal variation in $\mathrm{BP}$ and $\mathrm{BR}$, respectively, could be accounted for by seasonal changes in temperature. Previous studies estimating bacterial $\mathrm{C}$ processing in the Mediterranean over yearly cycles have found no (Lemée et al. 2002, Navarro et al. 2004) or very weak (Alonso-Sáez et al. 2008) correlations with temperature, and seasonal variations in BP and BR have not been explained by $\mathrm{P}$ availability (Lemée et al. 2002, Alonso-Sáez et al. 2008). In the above studies, $P$ was variable, and high $P$ availability coincided with low temperature, as $\mathrm{P}$ is generally entrained from deeper waters under nonstratified low-temperature periods. Hence, in these cases, the effect of temperature and $\mathrm{P}$ on bacterial $\mathrm{C}$ processing counter balance over the annual cycle leading to the observation of no patterns between bacterial $\mathrm{C}$ processing and $\mathrm{P}$ availability or temperature. In the current study, P concentrations remained low in winter and could not affect the large seasonal variation in $\mathrm{C}$ processing, allowing the role of temperature to emerge. Although $\mathrm{P}$ is limiting during most of the year, temperature seems to stimulate both BP and BR. Indeed, temperature explained more of the variation in $\mathrm{BR}$ in the P-amended treatments $(50 \%)$ than in the unamended controls (40\%). Similarly, in another seasonal study, BP was correlated to temperature after $\mathrm{P}$ limitation was relieved (Fig. 2 in Pinhassi et al. 2006; leucine incorporation in $\mathrm{P}$ - and $\mathrm{CP}$-amended treatments were higher during the warmer months of May to October than during winter).

The experimental temperature manipulations showed that BP and BR increased following a $2{ }^{\circ} \mathrm{C}$ temperature increase both in winter and summer, although the response was generally modest. However, at temperature increases higher than $2{ }^{\circ} \mathrm{C}, \mathrm{BP}$ and $\mathrm{BR}$ leveled off or decreased. The response in BP and BR to temperature manipulations was measured in experiments lasting $24 \mathrm{~h}$. Thus, we measured the response of the in situ community and did not allow for succession in response to the temperature change. It is possible that the response of $\mathrm{BP}$ and $\mathrm{BR}$ to temperatures $4^{\circ} \mathrm{C}$ or more above in situ reflected the specific temperature optima of the bacterial communities. Temperature is one of the factors structuring bacterial community composition, reflecting the existence of specific temperature optima for different bacterial phyla (Crump \& Hobbie 2005, Lymer et al. 2008). It is further possible that the strong resource limitation of these particular communities rendered them especially slow in adapting to new temperatures. The lipid composition of bacterial membranes is related to the ambient temperature with membrane composition being adjusted to maintain the fluidity, optimize substrate uptake, and minimize losses in the transmembrane proton gradient, which would increase the respiratory costs (Russell \& Fukunaga 1990). Adjusting membrane composition can be achieved either by alteration of existing lipids or de novo synthesis (Mansilla et al. 2004), both of which require energy and substrates that may not be at hand in highly oligotrophic environments, such as that studied here. Finally, other studies have found that BP and BR level off and/or decrease at temperatures around $30^{\circ} \mathrm{C}$ and above (Roland \& Cole 1999, Apple et al. 2006). As the temperature manipulation in summer included temperatures outside the normal range of this system, the bacterial community may not hold members that are adapted to such high temperatures. We conclude that the responses to temperature increase in these short experiments cannot be extrapolated to predict what would be the responses if the in situ temperature would increase by $2^{\circ}$ or more, a process that requires days. In addition, results from 2 dates only may not be representative with regards to the temperature effect on bacterial C processing. Nevertheless, the increase in $\mathrm{BP}$ and $\mathrm{BR}$ after increasing the temperature by $2^{\circ} \mathrm{C}$ is in line with the findings by Vázquez-Domínguez et al. (2007), who found a small but consistent increase in BP and BR after increasing the temperature by $2.5^{\circ} \mathrm{C}$ along an annual cycle.

Overall, our data suggest that elevated water temperatures may result in increased $\mathrm{BP}, \mathrm{BR}$, and $\mathrm{BCD}$. BP and BR were tightly coupled, although BP was less variable. Our findings concur with the hypothesis that under warm, oligotrophic conditions there is strong resource limitation of BP but not BR (López-Urrutia \& Morán 2007). The larger variability in BR suggests that more of the variability in BGE is explained by respiration, as has recently been suggested to be the case in oligotrophic surface waters (Reinthaler 2005). As a 
consequence of higher variability in BR and higher dependence of BR on temperature, BGE would be negatively related to temperature. This is in agreement with the conclusions made by Rivkin \& Legendre (2001) based on a cross system analysis. The correlation between BGE and temperature was just above the probability threshold $(\mathrm{p}=0.06)$. As suggested by Rivkin \& Legendre (2001), BR could be well predicted from BP and temperature. However, the response of $\mathrm{BR}$ to temperature was less pronounced in a model based on our data set $\left(4 \mathrm{mg} \mathrm{C} \mathrm{m} \mathrm{m}^{-3} \mathrm{~d}^{-1}{ }^{\circ} \mathrm{C}^{-1}\right)$ than the model based on their data set $\left(11 \mathrm{mg} \mathrm{C} \mathrm{m}^{-3} \mathrm{~d}^{-1}{ }^{\circ} \mathrm{C}^{-1}\right)$, which is probably a result of the significantly narrower resource gradient in our study compared to the cross system analyses by Rivkin \& Legendre (2001). In a recent cross system analysis, BP from a compiled data set was grouped according to the productivity of the system as determined from chl $a$, and it was then found that within oligotrophic, mesotrophic, and eutrophic systems, BP and BR responded strongly and in a similar manner to temperature, so that BGE was independent of temperature (López-Urrutia \& Morán 2007). The authors concluded that BP and the availability of substrates for growth regulate the variability in BGE. This conclusion may be valid for comparisons across systems, but does not explain the regulation of bacterial C processing within systems. Through both assessment over time at periods of contrasting water temperature and through experimental manipulations of temperature, we have shown that for the coastal NW Mediterranean site we studied, BP and BR are both affected by temperature, but BR is more strongly affected than BP. Moreover, both BP and BR are limited by resources (P), and the relative degree of limitation is variable and probably linked to the quality of the available organic matter.

The BGE values calculated in this study are high compared to predictions based on the model by Rivkin \& Legendre (2001; 0.08 to 0.22 ) and also compared to other studies from the NW Mediterranean. For instance, Vázquez-Domínguez et al. (2007) calculated an average of 0.12 , which is very similar to the mean of 0.11 estimated by Lemée et al. (2002). The reason for this discrepancy is probably methodological. All 3 studies base the BGE estimates on BP measured as leucine incorporation and BR as the consumption of oxygen in $0.8 \mu \mathrm{m}$ filtered water over 24 to $48 \mathrm{~h}$, and they use the same conversion factors. However, while Lemée and Vázquez-Domínguez and their co-workers used initial measurements of BP and assumed linear respiration throughout the incubation to calculate BGE, we used accumulated BP calculated from measurements made both initially and after $24 \mathrm{~h}$ and assumed exponential growth to avoid making assumptions about the linearity of respiration (Roland
\& Cole 1999). While the procedure adopted by Lemée et al. (2002) and Vázquez-Domínguez et al. (2007) is the more common in the literature, we believe that the constancy for BGE during the $24 \mathrm{~h}$ incubation is more robust than the constancy of the respiration rate throughout the incubation. As BP is evidently increasing strongly over $24 \mathrm{~h}$ (by 10-fold in VázquezDomínguez et al. (2007) and by 20-fold in our study), it is not likely that BR would stay at a constant level. If BR did stay constant, BGE would increase during the incubation, which seems improbable as logically the more labile substrates would be depleted during the experiment. Indeed, if we calculate BGE in the same way as Lemée and Vázquez-Domínguez and their coworkers, we arrive at a very similar level, i.e. $0.11 \pm$ 0.9 (SD).

Accurate assessment of BP requires the use of adequate leucine-to- $\mathrm{C}$ conversion factors. This conversion factor has been shown to vary seasonally and geographically (Murrell 2003, Alonso-Sáez et al. 2007, 2008), but was rather stable around an average of $1.7 \mathrm{~kg} \mathrm{C} \mathrm{mol}^{-1}$ leucine in an annual study in the NW Mediterranean (Alonso-Sáez et al. 2008) and thus close to the $1.5 \mathrm{~kg} \mathrm{C} \mathrm{mol}^{-1}$ leucine adopted in this study. To the extent that leucine-to- $C$ conversion factors may vary with environmental parameters, there has been a positive correlation with chl a and BGE (Alonso-Sáez et al. 2007, 2008). Adopting a somewhat higher and more variable conversion factor on this data set would result in higher $\mathrm{BP}$ and $\mathrm{BGE}$ numbers and a stronger relationship between $B G E$ and temperature, while the relationship between $\mathrm{BP}$ and temperature would be weakened. The overall conclusions, however, would remain unchanged. Assuming the double amount of $\mathrm{C}$ produced per mole leucine incorporated would change mean BP and BGE from $0.25 \mu \mathrm{g} \mathrm{C}^{-1} \mathrm{~h}^{-1}$ and 0.32 to $0.50 \mu \mathrm{g} \mathrm{C}^{-1} \mathrm{~h}^{-1}$ and 0.47 , respectively.

Our results do not fully agree with predictions of temperature and resource regulation of bacterial $\mathrm{C}$ cycling derived from cross system comparative analyses because the relationships inferred therein are affected by covariation between resource availability and temperature in the ocean. Hence, whereas cross system comparative analyses are important in deriving patterns in the ocean, manipulative experiments, such as those conducted here, have the capacity to separate the effects of these variables and, hence, formulate predictions on the effect of resource or temperature change in bacterial $\mathrm{C}$ cycling. Comparisons within and across systems and experimental manipulations are complementary approaches in understanding how bacterial $\mathrm{C}$ processing is regulated by temperature and resources. This knowledge is essential to understand the effects of global warming and the potential feedback mechanisms. 
Acknowledgements. This work was supported by a fellowship from the Swedish Research Council to E.K., a Ramón y Cajal fellowship to J.A. from the Spanish Ministry of Science and Technology, and by The Royal Physiographic Society in Lund, Sweden. We thank R. Santiago, R. Martínez, R. Sunyer, and J. Alonso for support with lab analyses.

\section{LITERATURE CITED}

Alonso-Sáez L, Gasol JM, Arístegui J, Vilas JC, Vaqué D, Duarte CM, Agustí S (2007) Large-scale variability in surface bacterial carbon demand and growth efficiency in the subtropical northeast Atlantic Ocean. Limnol Oceanogr 52:533-546

Alonso-Sáez L, Vazquez-Dominguez E, Cardelus C, Pinhassi $J$ and others (2008) Factors controlling the year-round variability in carbon flux through bacteria in a coastal marine system. Ecosystems 11:397-409

Apple JK, del Giorgo PA, Kemp WM (2006) Temperature regulation of bacterial production, respiration, and growth efficiency in a temperate salt-marsh estuary. Aquat Microb Ecol 43:243-254

Barrón C, Duarte CM (2009) Dissolved organic matter release in a Posidonia oceanica meadow. Mar Ecol Prog Ser 374: $75-84$

Cole JJ (1999) Aquatic microbiology for ecosystem scientists: new and recycled paradigms in ecological microbiology. Ecosystems 2:215-225

Cottrell MT, Kirchman DL (2000) Natural assemblages of marine proteobacteria and members of the CytophagaFlavobacter cluster consuming low- and high-molecularweight dissolved organic matter. Appl Environ Microbiol 66:1692-1697

Crump BC, Hobbie JE (2005) Synchrony and seasonality in bacterioplankton communities of two temperate rivers. Limnol Oceanogr 50:1718-1729

del Giorgio PA, Cole JJ (1998) Bacterial growth efficiency in natural aquatic systems. Annu Rev Ecol Syst 29:503-541

del Giorgio PA, Gasol JP, Vaqué D, Mura P, Agustí S, Duarte CM (1996) Bacterioplankton community structure: protists control net production and the proportion of active bacteria in a coastal marine community. Limnol Oceanogr 41: 1169-1179

Duarte CM, Agustí S, Vaqué D (2004) Controls on planktonic metabolism in the Bay of Blanes, northwestern Mediterranean littoral. Limnol Oceanogr 49:2162-2170

Eiler A, Langenheder S, Bertilsson S, Tranvik LJ (2003) Heterotrophic bacterial growth efficiency and community structure at different natural organic carbon concentrations. Appl Environ Microbiol 69:3701-3709

Fagerbakke KM, Heldal M, Norland S (1996) Content of carbon, nitrogen, oxygen, sulfur and phosphorus in native aquatic and cultured bacteria. Aquat Microb Ecol 10: 15-27

Fischer UR, Velimirov B (2002) High control of bacterial production by viruses in a eutrophic oxbow lake. Aquat Microb Ecol 27:1-12

Goldman JC, Dennett MR (1991) Ammonium regeneration and carbon utilization by marine bacteria grown on mixed substrates. Mar Biol 109:369-378

Goldman JC, Caron DA, Dennett MR (1987) Regulation of gross growth efficiency and ammonium regeneration in bacteria by substrate carbon to nitrogen ratio. Limnol Oceanogr 32:1239-1252

Hansen K, Koroleff F (1999) Detemination of nutrients. In: Grasshoff K, Kremling K, Ehrhardt M (eds) Methods of seawater analysis. Wiley-VCH, Weiheim, p 159-228
Kragh T, Sondergaard M, Tranvik L (2008) Effect of exposure to sunlight and phosphorus-limitation on bacterial degradation of coloured dissolved organic matter (CDOM) in freshwater. FEMS Microbiol Ecol 64:230-239

Kroer N (1993) Bacterial growth efficiency on natural dissolved organic matter. Limnol Oceanogr 38:1282-1290

> Lemée R, Rochelle-Newall E, Van Wambeke F, Pizay MD, Rinaldi P, Gattuso JP (2002) Seasonal variation of bacterial production, respiration and growth efficiency in the open NW Mediterranean Sea. Aquat Microb Ecol 29: $227-237$

> Lennon JT, Pfaff LE (2005) Source and supply of terrestrial organic matter affects aquatic microbial metabolism. Aquat Microb Ecol 39:107-119

López-Urrutia Á, Morán XAG (2007) Resource limitation of bacterial production distorts the temperature dependence of oceanic carbon cycling. Ecology 88:817-822

Lymer D, Logue JB, Brussaard CPD, Baudoux AC, Vrede K, Lindstrom ES (2008) Temporal variation in freshwater viral and bacterial community composition. Freshw Biol 53:1163-1175

Mansilla MC, Cybulski LE, Albanesi D, de Mendoza D (2004) Control of membrane lipid fluidity by molecular thermosensors. J Bacteriol 186:6681-6688

> Middelboe M, Sondergaard M (1993) Bacterioplankton growth yield: seasonal variations and coupling to substrate lability and beta-glucosidase activity. Appl Environ Microbiol 59:3916-3921

> Moutin T, Raimbault P (2002) Primary production, carbon export and nutrients availability in western and eastern Mediterranean Sea in early summer 1996 (MINOS cruise). J Mar Syst 33-34:273-288

Murrell MC (2003) Bacterioplankton dynamics in a subtropical estuary: evidence for substrate limitation. Aquat Microb Ecol 32:239-250

> Navarro N, Agustí S, Duarte CM (2004) Plankton metabolism and dissolved organic carbon use in the Bay of Palma, NW Mediterranean Sea. Aquat Microb Ecol 37:47-54

> Obernosterer I, Kawasaki N, Benner R (2003) P-limitation of respiration in the Sargasso Sea and uncoupling of bacteria from P-regeneration in size-fractionation experiments. Aquat Microb Ecol 32:229-237

Parsons TR, Maita Y, Lalli CM (1984) A manual of chemical and biological methods for seawater analysis. Pergamon, Oxford

> Pinhassi J, Gómez-Consarnau L, Alonso-Sáez L, Sala MM, Vidal M, Pedrós-Alió C, Gasol JM (2006) Seasonal changes in bacterioplankton nutrient limitation and their effects on bacterial community composition in the NW Mediterranean Sea. Aquat Microb Ecol 44:241-252

Pomeroy LR, Wiebe WJ (2001) Temperature and substrates as interactive limiting factors for marine heterotrophic bacteria. Aquat Microb Ecol 23:187-204

Reinthaler T (2005) Prokaryotic production and respiration in the open ocean. PhD dissertation, University of Groningen

Riemann L, Middelboe M (2002) Viral lysis of marine bacterioplankton: implications for organic matter cycling and bacterial clonal composition. Ophelia 56:57-68

Rivkin RB, Legendre L (2001) Biogenic carbon cycling in the upper ocean: effects of microbial respiration. Science 291: 2398-2400

Roland F, Cole JJ (1999) Regulation of bacterial growth efficiency in a large turbid estuary. Aquat Microb Ecol 20: $31-38$

Russell NJ, Fukunaga N (1990) A comparison of thermal adaptation of membrane lipids in psychrophilic and thermophilic bacteria. FEMS Microbiol Rev 75:171-182 
Smith DC, Azam F (1992) (1993)) A simple, economical method for measuring bacterial protein synthesis rates in seawater using tritiated-leucine. Mar Microb Food Webs 6:107-114

Smith EM, Prairie YT (2004) Bacterial metabolism and growth efficiency in lakes: the importance of phosphorus availability. Limnol Oceanogr 49:137-147

Thingstad FT, Zweifel UL, Rassoulzadegan F (1998) P limitation of heterotrophic bacteria and phytoplankton in the northwest Mediterranean. Limnol Oceanogr 43:88-94

Vallino JJ, Hopkinson CS, Hobbie JE (1996) Modeling bacterial utilization of dissolved organic matter: Optimization replaces monod growth kinetics. Limnol Oceanogr 41: 1591-1609

Editorial responsibility: Fereidoun Rassoulzadegan, Villefranche-sur-Mer, France,
Van Wambeke F, Christaki U, Giannakourou A, Moutin T, Souvemerzoglou K (2002) Longitudinal and vertical trends of bacterial limitation by phosphorus and carbon in the Mediterranean Sea. Microb Ecol 43:119-133

Vázquez-Domínguez E, Vaqué D, Gasol AM (2007) Ocean warming enhances respiration and carbon demand of coastal microbial plankton. Glob Change Biol 13: $1327-1334$

Wetzel RG, Likens GE (2000) Limnological analyses, 3rd edn. Springer, New York

Zohary T, Robarts RD (1998) Experimental study of microbial $\mathrm{P}$ limitation in the eastern Mediterranean. Limnol Oceanogr 43:387-395

Submitted: March 12, 2009; Accepted: August 27, 2009 Proofs received from author(s): November 11, 2009 